\title{
A Comparative Study of Partial Replacement of Wheat Flour with Whey and Soy Protein on Rheological Properties of Dough and Cookie Quality
}

\author{
Xiaozhi Tang and Junfei Liu \\ College of Food Science and Engineering/Collaborative Innovation Center for Modern Grain Circulation and Safety/Key Laboratory of \\ Grains and Oils Quality Control and Processing, Nanjing University of Finance and Economics, Nanjing 210023, China
}

Correspondence should be addressed to Xiaozhi Tang; warmtxz@163.com

Received 3 January 2017; Revised 31 March 2017; Accepted 12 April 2017; Published 11 May 2017

Academic Editor: Susana Fiszman

Copyright (C) 2017 Xiaozhi Tang and Junfei Liu. This is an open access article distributed under the Creative Commons Attribution License, which permits unrestricted use, distribution, and reproduction in any medium, provided the original work is properly cited.

\begin{abstract}
The development of wheat-based foods that are enriched with proteins is increasingly popular. The purpose of this study was to compare the effects of partial replacement of wheat flour with whey and soy proteins $(0-30 \%)$ on the rheological properties of dough and cookie-making quality. The incorporation of whey protein (WP) diluted the concentration of gluten, leading to an increase in dough development time (MDT) and breakdown torque and a decrease in stability time (MST) and minimum torque (MMT). The gelation of WP during the heat treatment increased dough peak torque (MPT), $G^{\prime}$, and $G^{\prime \prime}$. As a contrast, the addition of soy protein (SP) increased dough MST, MDT, and MMT. The aggregation of SP helped increase $G^{\prime}$ and decrease $\tan \delta$ of the dough in oscillatory shear tests. The weak gelling effects and higher water absorption of SP decreased MPT, $G^{\prime}$, and $G^{\prime \prime}$ of the dough during heat treatment. With SP, the spread ratio of cookies first decreased from 6.39 to 5.66 and then increased to 6.86, and the overall acceptability scores ranged from 6.62 to 7.02 , indicating that the formed soy protein network helped maintain the dough structure for obtaining an improvement in the quality of bakery products.
\end{abstract}

\section{Introduction}

Currently, with increasing concern regarding the nutrition and flavor of food products, the development of wheatbased bakery foods that are enriched with foreign protein additives is increasingly popular [1]. Whey proteins are the best quality proteins available and have high digestibility and a complete amino acid profile. Whey proteins are also recommended due to their beneficial effects on enhancing immunity and reducing the risk of heart disease and the incidence of cancer [2]. Soybean contains the highest quality and quantity protein of any other plant sources and is an inexpensive source of protein and calories for human consumption and in addition, it is seen as a low cost substitute for milk proteins in developing countries [3]. Soy proteins are also reported having beneficial effects on nutrition and health, such as prevention of cancer, diabetes, and obesity and protection against bowel and kidney diseases. Both whey and soy proteins are the most used proteins in protein fortified food products.

There were several reports of the effect of whey or soy proteins on the properties of wheat dough and wheat-based bakery products [3-8]. Since it is known that the gluten network is responsible for viscoelastic properties in wheat dough and for dough structure strength and gas retention, most studies above reported that the incorporation of foreign proteins interfered with gluten development and therefore had negative effects on baking products, especially when amount of foreign proteins was higher than $5 \%$. Although initially the aim of addition of proteins was to increase the nutritional value of wheat-based bakery products, whey and soy proteins exhibit various functional properties including solubility, gelation, viscosity, emulsifying action, moisture holding capacity, and foam-stabilizing activity, which might significantly impact the structure of the dough and the quality of the some types of products $[5,9,10]$. For example, 
the ability of whey proteins to thicken and form a gel upon heating might be advantageous for some applications; however, this ability might also be disadvantageous for others [11]. Therefore, the selection of the protein source with appropriate functionality might play an important role in certain application. In addition, if a continuous protein phase could be created when amount of foreign proteins was higher than gluten in wheat flour, they might confer a protective effect on dough structure for obtaining an improvement in the quality of bakery products.

Therefore, the objective of this study was to compare the effect of whey and soy protein addition on the thermomechanical, dynamic rheological and microstructural properties of wheat dough and the cookie-making quality. A relatively wide range of foreign protein addition $(0-30 \%)$ to wheat dough was tested. Such a study is essential for product development and process control when considering the popularity of protein fortified bakery products.

\section{Materials and Methods}

2.1. Materials. Wheat flour was obtained from Shenzhen Southseas Grains Industries Ltd. (Shenzhen, China), which contained protein of $8.53 \%$, fat of $1.15 \%$, ash of $0.28 \%$ (dry weight basis), and $12.09 \%$ moisture. Whey protein was purchased from Fonterra Co-operative Group Limited (Aucklan, New Zealand). It contains $76.44 \%$ protein and $6.69 \%$ moisture. Soy protein was obtained from Yihai Kerry Groups (Qinhuangdao, China) with $86.58 \%$ protein and $6.81 \%$ moisture. Whey and soy proteins were mixed with wheat flour at seven substitution levels $(0 \%, 5 \%, 10 \%, 15 \%$, $20 \%, 25 \%$, and $30 \%$ ) for further tests.

2.2. Mixolab Measurements. The thermomechanical characteristics of the samples were determined using a Mixolab (Chopin, Paris, France). For the assays, a certain amount of wheat-protein blends with known moisture content was placed into the Mixolab bowl and mixed to obtain dough of $75 \mathrm{~g}$. After tempering the solids, the water required for the dough to produce a torque of $1.1 \mathrm{Nm}$ was automatically added by the Mixolab system. The settings used in the test were as follows: (1) the temperature was kept constant at $30^{\circ} \mathrm{C}$ for $8 \mathrm{~min}$; (2) then the temperature was raised to $90^{\circ} \mathrm{C}$ at a rate of $4^{\circ} \mathrm{C} / \mathrm{min}$, holding for $7 \mathrm{~min}$; (3) the temperature was cooled to $50^{\circ} \mathrm{C}$ at a rate of $4^{\circ} \mathrm{C} / \mathrm{min}$, holding for another $5 \mathrm{~min}$. The mixing speed during the entire analysis was $80 \mathrm{rpm}$. The processes were repeated three times for each sample.

The following parameters were obtained from Mixolab measurements [12]: Mixolab water absorption (MWA); Mixolab development time (MDT); Mixolab stability time (MST); Mixolab minimum torque (MMT); Protein weakening (PW); Pasting temperature (PT), Mixolab peak torque (MPT); Mixolab breakdown torque (MBD); Mixolab setback torque (MSB).

2.3. Dough Stickiness. Dough stickiness (DS) was determined with a Texture Analyzer (TA-XT2i, Stable Micro Systems, Godalming, UK) using a Chen and Hoseney cell
[13]. The settings were as follows: compression force $40 \mathrm{~g}$; plexiglass probe diameter $25 \mathrm{~mm}$; trigger force $5 \mathrm{~g}$, pretest speed $2 \mathrm{~mm} / \mathrm{s}$, posttest speed $10 \mathrm{~mm} / \mathrm{s}$, holding time $0.1 \mathrm{~s}$, and probe travel distance $4 \mathrm{~mm}$. The force required for separating the probe from the dough surface was recorded. Triplicate measurements were performed.

2.4. Rheological Measurements. The dynamic rheological properties of the dough were determined using a controlledstress rheometer (MCR 302, Anton Paar, Austria). The plateplate geometry was used with a diameter of $50 \mathrm{~mm}$ and a gap between plates of $1 \mathrm{~mm}$. Assayed doughs were previously prepared using Mixolab when the torque reached 1.1 Nm. Oil was used to prevent the samples drying during tests. A rest time of 15 min was applied to all samples before measuring. Three replicates of each measurement were made.

Stress sweep tests at $1.0 \mathrm{~Hz}$ were firstly conducted in order to define the linear viscoelasticity zone in the range of strain from $0.01 \%$ to $1 \%$; frequency sweep tests were performed in the range of 1 to $100 \mathrm{rad} / \mathrm{s}$ at a strain value of $0.1 \%$ to determine the storage modulus $\left(G^{\prime}\right)$, loss modulus $\left(G^{\prime \prime}\right)$, and $\tan \delta\left(G^{\prime \prime} / G^{\prime}\right)$.

The temperature sweep tests were then performed at a strain of $0.1 \%$ and frequency of $1 \mathrm{~Hz}$. Dough was heated in the rheometer cell from 30 to $90^{\circ} \mathrm{C}$ at $5^{\circ} \mathrm{C} / \mathrm{min}$. The storage modulus $\left(G^{\prime}\right)$ and the loss modulus $\left(G^{\prime \prime}\right)$ were recorded as a function of temperature.

2.5. Scanning Electron Microscopy. The microstructure of the dough was observed by scanning electron microscopy. For the assay, the samples were fixed in 3\% glutaraldehyde for $2 \mathrm{~h}$ and embedded in a graded ethanol series $(30 \%, 50 \%, 70 \%$, and $90 \%$ ) for $20 \mathrm{~min}$ at each gradation. After that, samples were embedded in $100 \%$ ethanol for three consecutive $20 \mathrm{~min}$ intervals to ensure full dehydration and then freeze-dried. Fragments of the freeze-dried samples were mounted on aluminium specimen stubs using doubled tape and sputtercoated with a layer of gold by Ion Sputter. Sample analysis was performed at an accelerating voltage of $15 \mathrm{kV}$ with SEM (TM3000, Hitachi, Japan).

2.6. Cookie Preparation and Quality Evaluation. Cookies were prepared according to AACC $10-50 D$. The diameter $(D)$, thickness $(T)$, and spread ratio $(D / T)$ were determined according to AACC standard method $10-50 D$ [14]. The hardness of cookies was determined using three-point break (HDP/3 PB) technique with a Texture Analyzer (TA-XT2i, Stable Micro Systems, Godalming, UK). The pretest speed was set at $3.0 \mathrm{~mm} / \mathrm{s}$, test speed at $1.0 \mathrm{~mm} / \mathrm{s}$, and posttest speed at $10.0 \mathrm{~mm} / \mathrm{s}$. Probe travel distance was set at $10 \mathrm{~mm}$ and data acquisition rate at $500 \mathrm{pps}$. The maximum breaking force was recorded, which could be referred to as the hardness of the cookies. Seven replicates were performed for each test. The color was measured as a series of $L^{*}, a^{*}$, and $b^{*}$ values by colorimeter (Konica Minolta, Japan). Each assay was repeated 10 times, and the average value was used. Color difference $(\Delta E)$ was defined as the difference between samples and 
TABLE 1: Effect of whey and soy protein addition on thermomechanical properties and stickiness of wheat dough ${ }^{\mathrm{a}}$.

\begin{tabular}{|c|c|c|c|c|c|c|c|c|c|c|}
\hline & $\begin{array}{c}\text { MWA } \\
(\%)\end{array}$ & $\begin{array}{l}\text { MDT } \\
(\mathrm{min})\end{array}$ & $\begin{array}{l}\text { MST } \\
(\mathrm{min})\end{array}$ & $\begin{array}{l}\text { MMT } \\
(\mathrm{Nm})\end{array}$ & $\begin{array}{c}\mathrm{PW} \\
(\mathrm{Nm})\end{array}$ & $\begin{array}{c}\mathrm{PT} \\
\left({ }^{\circ} \mathrm{C}\right) \\
\end{array}$ & $\begin{array}{l}\text { MPT } \\
(\mathrm{Nm})\end{array}$ & $\begin{array}{l}\mathrm{MBD} \\
(\mathrm{Nm})\end{array}$ & $\begin{array}{l}\text { MSB } \\
(\mathrm{Nm})\end{array}$ & $\begin{array}{l}\text { DS } \\
(\mathrm{g}) \\
\end{array}$ \\
\hline Control & 53.8 & $\begin{array}{l}1.12 \pm \\
0.07^{\mathrm{ab}}\end{array}$ & $\begin{array}{c}7.62 \pm \\
0.28^{c}\end{array}$ & $0.50 \pm 0^{\mathrm{e}}$ & $\begin{array}{c}0.63 \pm \\
0.01^{\mathrm{e}}\end{array}$ & $\begin{array}{c}55.60 \pm \\
0.26^{\mathrm{a}}\end{array}$ & $\begin{array}{c}2.21 \pm \\
0.03^{\mathrm{c}}\end{array}$ & $\begin{array}{c}0.42 \pm \\
0.02^{\mathrm{a}}\end{array}$ & $\begin{array}{c}1.67 \pm \\
0.01^{\mathrm{c}}\end{array}$ & $\begin{array}{c}23.37 \pm \\
9.64^{\mathrm{a}}\end{array}$ \\
\hline \multicolumn{11}{|c|}{ Whey protein } \\
\hline 5 & 49.8 & $\begin{array}{c}2.66 \pm \\
0.39^{\mathrm{c}}\end{array}$ & $\begin{array}{l}4.63 \pm \\
0.08^{\mathrm{ab}}\end{array}$ & $0.30 \pm 0^{c}$ & $0.80 \pm 0^{g}$ & $\begin{array}{c}58.25 \pm \\
0.35^{\mathrm{bc}}\end{array}$ & $\begin{array}{l}2.28 \pm \\
0.01^{\mathrm{c}}\end{array}$ & $\begin{array}{l}0.59 \pm \\
0.03^{\mathrm{ab}}\end{array}$ & $0.9 \pm 0.03^{\mathrm{a}}$ & $\begin{array}{c}44.76 \pm \\
12.31^{\mathrm{b}}\end{array}$ \\
\hline 10 & 47.1 & $\begin{array}{c}3.35 \pm \\
0.04^{\mathrm{c}}\end{array}$ & $\begin{array}{c}3.76 \pm \\
0.95^{\mathrm{a}}\end{array}$ & $\begin{array}{c}0.24 \pm \\
0.01^{\mathrm{b}}\end{array}$ & $\begin{array}{l}0.82 \pm \\
0.01^{\mathrm{gh}}\end{array}$ & $\begin{array}{c}58.30 \pm \\
0.99^{\mathrm{bc}}\end{array}$ & $2.3 \pm 0.01^{\mathrm{c}}$ & $0.63 \pm 0^{\mathrm{bc}}$ & $\begin{array}{c}0.89 \pm \\
0.03^{\mathrm{a}}\end{array}$ & $\begin{array}{c}65.31 \pm \\
23.49^{c}\end{array}$ \\
\hline 15 & 44.2 & $\begin{array}{l}4.13 \pm \\
0.08^{\mathrm{d}}\end{array}$ & $\begin{array}{c}3.75 \pm \\
0.04^{\mathrm{a}}\end{array}$ & $0.23 \pm 0^{\mathrm{b}}$ & $0.85 \pm 0^{\mathrm{h}}$ & $\begin{array}{c}60.20 \pm \\
0.71^{\mathrm{cd}}\end{array}$ & $2.49 \pm 0^{\mathrm{d}}$ & $\begin{array}{c}0.84 \pm \\
0.01^{c}\end{array}$ & $0.8 \pm 0.05^{\mathrm{a}}$ & $\begin{array}{r}112.31 \pm \\
3.54^{\mathrm{d}}\end{array}$ \\
\hline 20 & 43.2 & $\begin{array}{l}4.42 \pm \\
0.02^{\mathrm{d}}\end{array}$ & $\begin{array}{c}3.66 \pm \\
0.08^{\mathrm{a}}\end{array}$ & $\begin{array}{c}0.20 \pm \\
0.01^{\mathrm{b}}\end{array}$ & $0.89 \pm 0^{\mathrm{i}}$ & $\begin{array}{c}60.60 \pm \\
0.28^{\text {cd }}\end{array}$ & $\begin{array}{c}2.75 \pm \\
0.01^{\mathrm{e}}\end{array}$ & $\begin{array}{l}1.26 \pm \\
0.14^{\mathrm{d}}\end{array}$ & $0.8 \pm 0.15^{\mathrm{a}}$ & $\begin{array}{c}136.98 \pm \\
11.66^{\mathrm{e}}\end{array}$ \\
\hline 25 & 43.0 & $\begin{array}{l}4.28 \pm \\
0.22^{\mathrm{d}}\end{array}$ & $\begin{array}{c}4.23 \pm \\
0.18^{\mathrm{a}}\end{array}$ & $0.11 \pm 0^{\mathrm{a}}$ & $\begin{array}{c}0.97 \pm \\
0.02^{j}\end{array}$ & $\begin{array}{c}62.20 \pm \\
0.41^{\mathrm{d}}\end{array}$ & $\begin{array}{c}2.84 \pm \\
0.06^{\mathrm{e}}\end{array}$ & $\begin{array}{c}1.93 \pm \\
0.01^{\mathrm{e}}\end{array}$ & $\begin{array}{c}0.93 \pm \\
0.02^{\mathrm{a}}\end{array}$ & $\begin{array}{r}131.57 \\
17.93^{\mathrm{e}}\end{array}$ \\
\hline 30 & 42.7 & $\begin{array}{l}4.22 \pm \\
0.35^{\mathrm{d}}\end{array}$ & $\begin{array}{l}5.26 \pm \\
0.23^{\mathrm{ab}}\end{array}$ & $\begin{array}{c}0.12 \pm \\
0.01^{\mathrm{a}}\end{array}$ & $\begin{array}{c}0.97 \pm \\
0.02^{j}\end{array}$ & $\begin{array}{c}61.80 \pm \\
0.71^{\mathrm{d}}\end{array}$ & $\begin{array}{c}3.05 \pm \\
0.04^{\mathrm{f}}\end{array}$ & $\begin{array}{l}2.31 \pm \\
0.06^{f}\end{array}$ & $\begin{array}{c}0.99 \pm \\
0.06^{\mathrm{a}}\end{array}$ & $\begin{array}{c}142.71 \\
9.96^{\mathrm{e}}\end{array}$ \\
\hline \multicolumn{11}{|c|}{ Soy protein } \\
\hline 5 & 58.8 & $\begin{array}{c}0.81 \pm \\
0.11^{\mathrm{a}}\end{array}$ & $\begin{array}{c}5.90 \pm \\
0.29^{\mathrm{b}}\end{array}$ & $\begin{array}{c}0.43 \pm \\
0.01^{\mathrm{d}}\end{array}$ & $\begin{array}{c}0.67 \pm \\
0.01^{\mathrm{f}}\end{array}$ & $\begin{array}{c}56.73 \pm \\
0.57^{\mathrm{ab}}\end{array}$ & $\begin{array}{c}2.00 \pm \\
0.01^{\mathrm{b}}\end{array}$ & $\begin{array}{c}0.55 \pm \\
0.01^{\mathrm{ab}}\end{array}$ & $\begin{array}{l}1.40 \pm \\
0.02^{\mathrm{b}}\end{array}$ & $\begin{array}{c}19.17 \pm \\
5.93^{\mathrm{a}}\end{array}$ \\
\hline 10 & 65.1 & $\begin{array}{c}1.53 \pm \\
0.10^{\mathrm{b}}\end{array}$ & $\begin{array}{l}8.40 \pm \\
0.91^{\mathrm{cd}}\end{array}$ & $0.50 \pm 0^{\mathrm{e}}$ & $\begin{array}{l}0.61 \pm \\
0.02^{\mathrm{de}}\end{array}$ & $\begin{array}{c}57.23 \pm \\
0.75^{\mathrm{ab}}\end{array}$ & $\begin{array}{c}1.77 \pm \\
0.01^{\mathrm{a}}\end{array}$ & $\begin{array}{l}0.70 \pm \\
0.04^{\mathrm{bc}}\end{array}$ & $\begin{array}{c}1.44 \pm \\
0.04^{\mathrm{b}}\end{array}$ & $\begin{array}{c}15.99 \pm \\
3.14^{\mathrm{a}}\end{array}$ \\
\hline 15 & 72.0 & $\begin{array}{c}1.61 \pm \\
0.03^{\mathrm{b}}\end{array}$ & $\begin{array}{l}8.99 \pm \\
0.15^{\text {cde }}\end{array}$ & $\begin{array}{c}0.55 \pm \\
0.01^{\mathrm{f}}\end{array}$ & $\begin{array}{c}0.58 \pm \\
0.02^{\mathrm{d}}\end{array}$ & - & - & - & - & $\begin{array}{c}15.35 \pm \\
3.59^{\mathrm{a}}\end{array}$ \\
\hline 20 & 79.3 & $\begin{array}{l}1.67 \pm \\
0.18^{\mathrm{b}}\end{array}$ & $\begin{array}{l}9.83 \pm \\
0.34^{\mathrm{de}}\end{array}$ & $\begin{array}{c}0.58 \pm \\
0.01^{\mathrm{f}}\end{array}$ & $\begin{array}{c}0.53{ }^{ \pm} \\
0.01^{c}\end{array}$ & - & - & - & - & $\begin{array}{c}16.98 \pm \\
2.93^{\mathrm{a}}\end{array}$ \\
\hline 25 & 87.0 & $\begin{array}{c}1.63 \pm \\
0.06^{\mathrm{b}}\end{array}$ & $\begin{array}{c}10.01 \pm \\
0.13^{\mathrm{e}^{ \pm}}\end{array}$ & $\begin{array}{c}0.62 \pm \\
0.03^{\mathrm{g}}\end{array}$ & $\begin{array}{c}0.48 \pm \\
0.02^{\mathrm{b}}\end{array}$ & - & - & - & - & $\begin{array}{c}14.80 \pm \\
1.68^{\mathrm{a}}\end{array}$ \\
\hline 30 & 94.4 & $\begin{array}{l}1.63 \pm \\
0.22^{\mathrm{b}}\end{array}$ & $\begin{array}{c}10.47 \pm \\
0.54^{\mathrm{e}}\end{array}$ & $\begin{array}{c}0.66 \pm \\
0.01^{\mathrm{h}}\end{array}$ & $\begin{array}{c}0.44 \pm \\
0.01^{\mathrm{a}}\end{array}$ & - & - & - & - & $\begin{array}{c}13.77 \pm \\
2.66^{\mathrm{a}}\end{array}$ \\
\hline
\end{tabular}

${ }^{\mathrm{a}}$ Data are presented as means \pm standard deviation. Data values with different letters in columns are significantly different, $p \leq 0.05$.

standard white porcelain on color, which was calculated using the following equation:

$$
\Delta E=\sqrt{\left(L^{*}-L_{s}\right)^{2}+\left(a^{*}-a_{s}\right)^{2}+\left(b^{*}-b_{s}\right)^{2}},
$$

where $L_{s}, a_{s}$, and $b_{s}$ are values of standard white porcelain, $97.13,0.21$, and 1.87 , respectively, and $L^{*}, a^{*}$, and $b^{*}$ are the determined values of cookies.

2.7. Consumer Acceptability Test. The consumer acceptability study was carried out in the Sensory Evaluation Analysis Laboratory of College of Food Science and Engineering at Nanjing University of Finance and Economics, Nanjing, China. A consumer panel consisting of 50 subjects was recruited to rate cookies on their overall acceptability and other attributes. All panelists were cookie consumers. A 9point hedonic scale ( 1 = "dislike extremely," 5 = "neither like nor dislike," and $9=$ "like extremely") was used to evaluate the products. Cookies were rated for overall acceptability, acceptability of hardness, texture/mouth feel, color/appearance, and flavor. Cookies with an overall acceptability score above 5 were considered as acceptable. The cookies were prepared 1 day prior to testing and stored at room temperature in sealed plastic bags. All the samples were randomized using 3-digit codes. The order of the treatments served to the consumers was also random. Drinking water was used to cleanse mouth between the samples.

2.8. Statistical Analysis. Statistical analysis of the data was performed using Origin 9.0 (OriginLab Corp., Northampton, MA). Statistical significance of differences in means was calculated using ANOVA and Bonferroni's multiple comparison tests at $p<0.05$.

\section{Results and Discussion}

3.1. Mixolab Measurements. Mixolab allows the characterization of the physicochemical behavior of protein and starch in dough when subjected to dual mechanical shear and temperature constraints (Table 1). Whey protein (WP) incorporation (0\% 30\%) decreased MWA of wheat dough from $53.8 \%$ to 42.7\%. Indrani et al. [5] also reported that the substitution of wheat flour with WP decreased water absorption. As the substitution level of WP increased from $0 \%$ to $20 \%$, MDT increased and MST decreased. However, as the WP level was further increased to $30 \%$, no significant changes for MDT but MST increased from 3.66 to $5.26 \mathrm{~min}$. Dough development 
time (MDT) and stability time (MST) are indicators of flour strength, with higher values suggesting stronger dough, in which wheat gluten plays a critical role in the formation of a three-dimensional viscoelastic structure [15]. The addition of WP led to a complex system and delayed the hydration and stretching and alignment of the wheat gluten, leading to the increase of MDT. MST decreased due to the dilution of wheat gluten and WP interference with the gluten network. Zadow [16] reported that wheat flour dough weakening by WP is due to interference by WP sulfhydryl groups of the normal sulfhydryl/disulfide interchange reaction that occurs during wheat flour dough development. At concentration greater than 20\%, the addition of WP significantly increased dough stickiness (DS, Table 1) and subsequently increased MST. Dough MMT reflects a weakening of wheat protein. The addition of WP diluted the concentration of gluten and destroyed the continuous state of the wheat flour dough, rendering it difficult to form a stable gluten network structure under the double effects of mechanical force and heating; thus MMT continued to decrease and PW continued to increase.

During the heating stage, starch granules absorb water available in the medium and swell. Amylose chains leach out into the aqueous intergranular phase, promoting an increase in viscosity and leading to peak in torque. With increasing WP, PT also significantly increased. WP addition decreased dough water absorption. At the same time, WP is expected to compete for water with the primary starch chains during heating, and this might cause the observed pasting temperature to increase [17]. MPT significantly increased, possibly due to WP gelation. Marco and Rosell [18] reported that the thermally induced gelation of the proteins developed during the heat treatment, which greatly modified rheological behaviors of the dough. WP forms viscoelastic gels upon heating above its denaturation temperature [19].

In response to the addition of WP, MBD increased, indicating that the addition of WP reduced the thermal stability of the starch in dough. The addition of WP destroyed the continuous gluten network structure and subsequently weakening its protective effect on starch subjected to amylase. As the substitution level of WP increased, MSB of the dough first decreased and then increased. MSB might have decreased because the proportion of starch decreased. At higher WP concentrations, the strengthening of the WP gel during the cooling stage might have caused the rise again in MSB.

Compared to WP, wheat flour-soy protein (SP) dough exhibited different behaviors in Mixolab measurements. The incorporation of SP ( $0 \%$ 30\%) increased MWA from 53.8\% to $94.4 \%$ in wheat flour dough. MDT, MST, and MMT first decreased at $5 \%$ substitution level and then continually increased with the further increase of SP level from 5 to $30 \%$. The increase of above parameters in the presence of $\mathrm{SP}$ was attributed to the aggregation of SP and its higher water binding capacity in the dough system, which increased the mechanical tolerance of the dough $[9,20]$. However, in the heating stage, no Mixolab data were obtained when SP substitution level was higher than $10 \%$. This was probably because of higher percentage of water absorption by SP. The dough could not hold the water under the double effects of mechanical shear and heating. The Mixolab mechanical arm skidded in the process of mixing; therefore the instrument could not detect the torque value. From the existing data, it was observed that MPT significantly decreased with increasing level of SP possibly due to lower content of starch and higher amount of water in the dough.

3.2. Dough Stickiness. Stickiness (DS) of whey and soy protein enriched wheat flour dough was also shown in Table 1. With increasing WP content, the stickiness of the dough increased from 23.37 to $142.71 \mathrm{~g}$, whereas the stickiness of the dough with addition of soy protein decreased from 23.37 to $13.77 \mathrm{~g}$. Dough stickiness is caused by an interactive balance between adhesion and cohesion [21]. Adhesion represents the interaction between a material (dough) and a surface (probe), whereas cohesion describes the interactions inside the dough [22]. In wheat flour, gluten absorbed water to induce protein interactions that play a critical role in dough stickiness [23]. As the WP content increased, the hydration of WP resulted in higher surface adhesion, which played a leading role in the increase of dough stickiness. However, in wheat-SP dough, dilution of gluten and higher percentage of water led to a sharp decrease of dough stickiness.

3.3. Rheological Measurements. The rheological properties of WP and SP enriched wheat flour dough were studied using a controlled-stress rheometer and the results were shown in Figure 1. The storage modulus $\left(G^{\prime}\right)$ is a measure of the solid or elastic character of the dough, and the loss modulus $\left(G^{\prime \prime}\right)$ is a measure of the liquid or viscous character; $\tan \delta\left(G^{\prime \prime} / G^{\prime}\right)$ indicates the relative contributions of the viscous and elastic characteristics of the dough. Figure 1 showed that that $G^{\prime}$ and $G^{\prime \prime}$ decreased and $\tan \delta$ increased with increasing WP proportion in wheat doughs, indicating a weakened gluten network. However, $G^{\prime}$ increased and $G^{\prime \prime}$ and $\tan \delta$ decreased with increasing SP proportion in wheat doughs, potentially due to soy protein aggregation within the medium. It was reported that SP can increase disulphide linkage, providing elasticity for baked goods $[9,18]$. The results were also consistent with the rheological measurements taken by Mixolab. The addition of WP softened the dough system due to the interference with the gluten network [6], while soy protein enhanced stability and elasticity of the dough.

All protein enriched wheat doughs demonstrated an increase in storage and loss modulus with increase in frequency (Figure 1). However, the addition of WP increased the frequency dependence as indicated by the increase of the $\tan \delta$ slope compared to that of wheat dough control (Figure 1(b)). All dough samples showed a soft gel-like viscoelastic behavior with $G^{\prime}$ higher than $G^{\prime \prime}$, except the dough with $30 \%$ WP substitution which showed a crossover at $15.8 \mathrm{rad} / \mathrm{s}$. This crossover was associated with a change in the viscoelastic behavior, suggesting that the viscous component became more relevant than elastic one when frequency was higher than $15.8 \mathrm{rad} / \mathrm{s}$.

Temperature sweep of doughs with different WP and SP substitution levels was shown in Figure 2. During the tests, three distinct stages of dynamic rheological changes were 


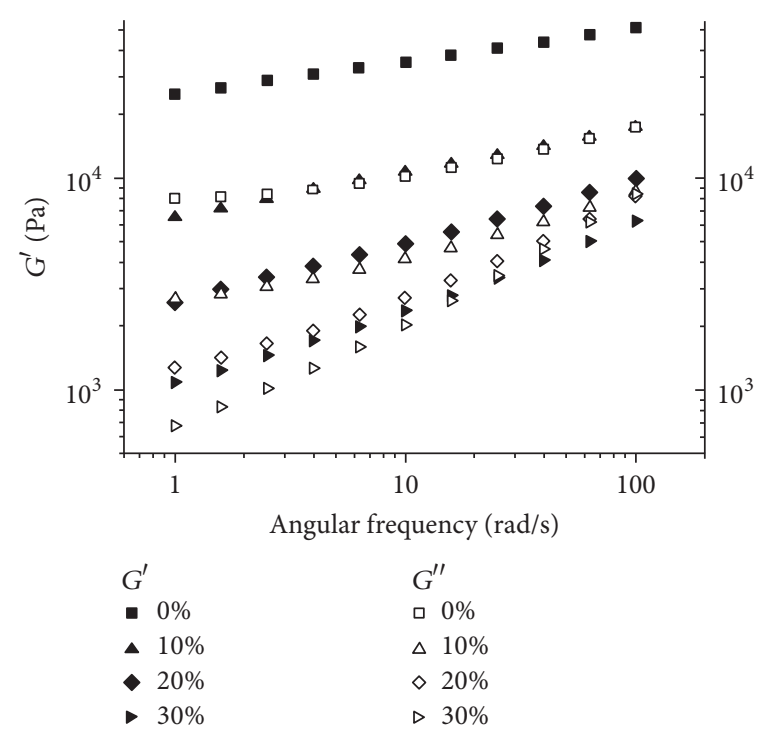

(a)

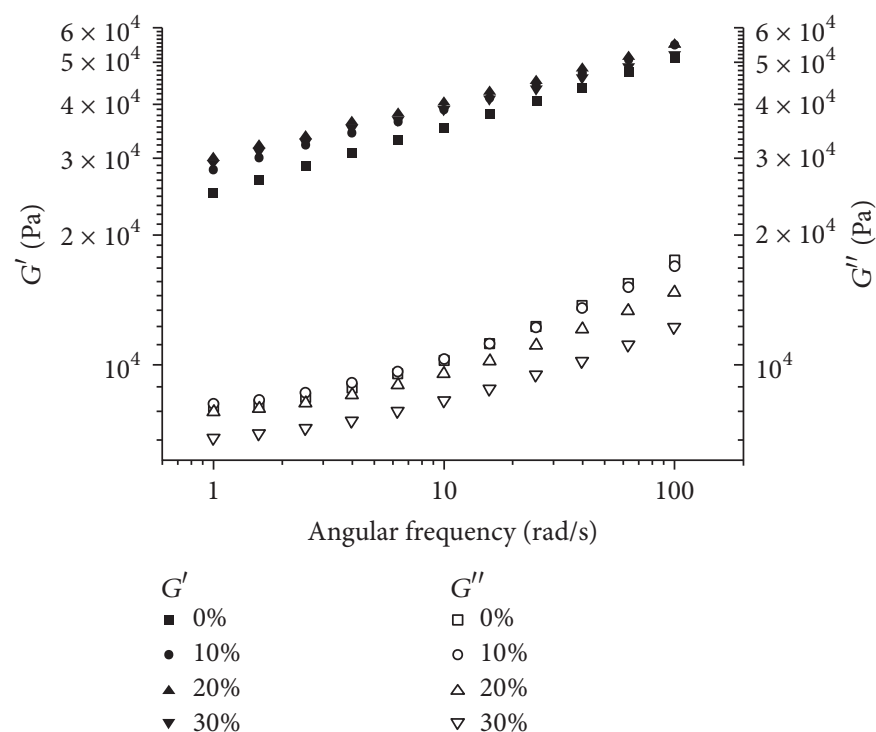

(c)

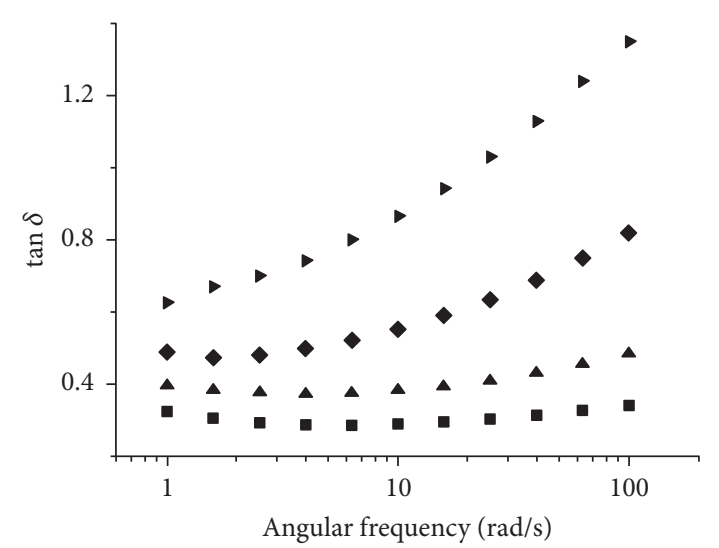
$\tan \delta$
- $0 \%$
- $10 \%$
- $20 \%$
- $30 \%$

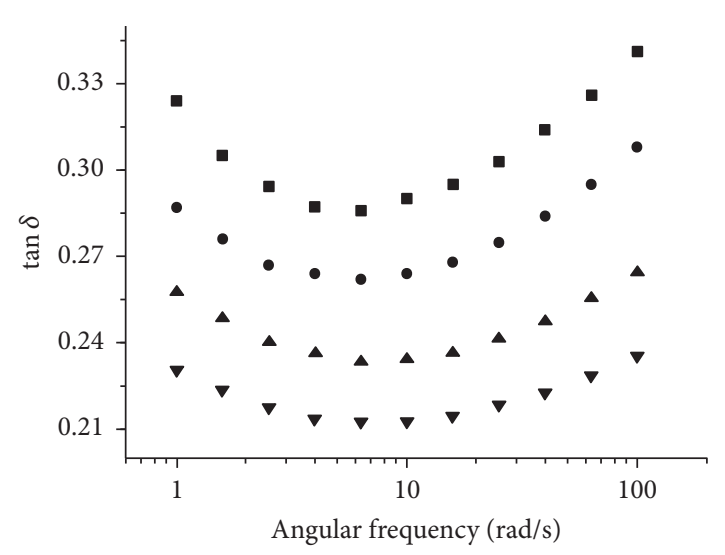

$\tan \delta$

- $0 \%$

- $10 \%$

- $20 \%$

- $30 \%$

(d)

FIGURE 1: The effect of whey and soy protein addition on $G^{\prime}, G^{\prime \prime}$, and $\tan \delta$ of wheat dough with frequency sweep: WP ((a), (b)); SP ((c), (d)).

observed. For wheat dough, the first stage was observed from $30^{\circ} \mathrm{C}$ to $54^{\circ} \mathrm{C}$. As the temperature increased, the values of $G^{\prime}$ and $G^{\prime \prime}$ decreased slightly, possibly due to hydrolysis of damaged starch by amylase. The second stage was observed at temperatures above $54^{\circ} \mathrm{C}$. At this stage, $G^{\prime}$ increased rapidly and reached a maximum value at $72^{\circ} \mathrm{C}$, indicating the gelatinization of starch. During gelatinization, amylose chains leached out into the aqueous intergranular phase, increasing dough viscosity and elasticity [24]. At the third stage, starch gelatinization was complete and $G^{\prime}$ and $G^{\prime \prime}$ began to decrease because of starch degradation. Upon the addition of WP, the transition temperature and the temperature at which the maximum value of $G^{\prime}$ and $G^{\prime \prime}$ was observed were clearly delayed and dependent on the amount of WP added. The increase in transition temperature was consistent with the results obtained using Mixolab, which indicated that WP would compete for water with the starch and gluten molecules in the dough system. The peak value of $G^{\prime}$ and $G^{\prime \prime}$ of the dough significantly increased with the increasing level of WP from 0 to $20 \%$ and slightly decreased with further increase of WP level to $30 \%$. The heat-induced gelation of WP was mainly responsible for the increase of $G^{\prime}$ and $G^{\prime \prime}$. In addition, heat treatment of WP changes its structure from the native, compact folded to a denatured, unfolded structure [6]. Therefore, the sites for cross-linking among proteins and starches increase with an increase in protein concentration, which will subsequently affect the properties of the dough. It was reported that WP/cassava starch composite gels containing up to $20 \%$ cassava starch in the system showed enhanced viscoelastic properties as compared to gels made from either 


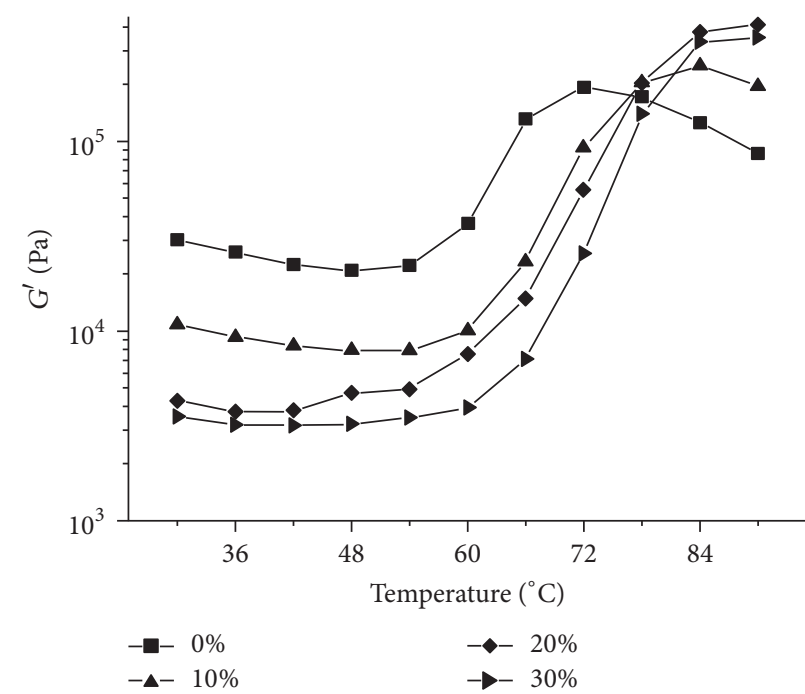

(a)

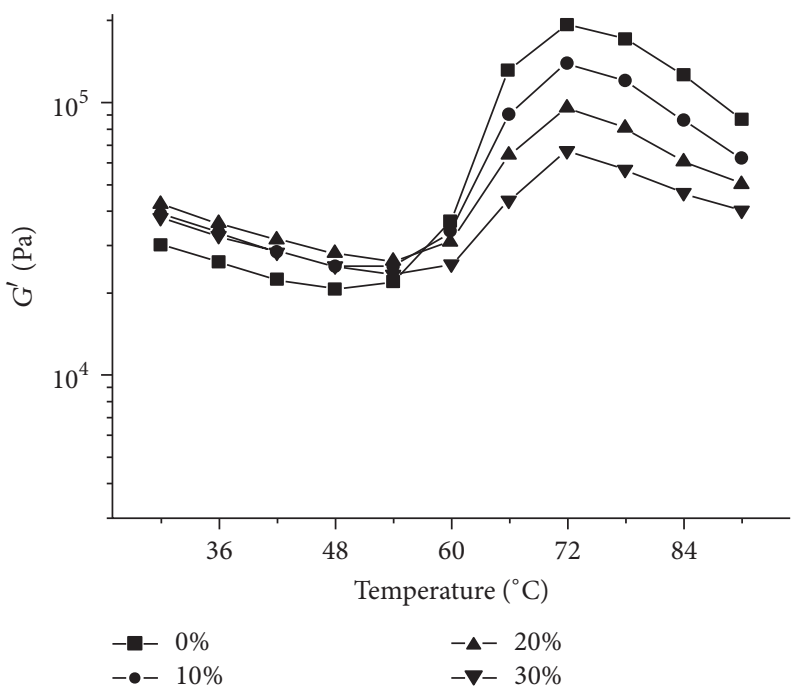

(c)

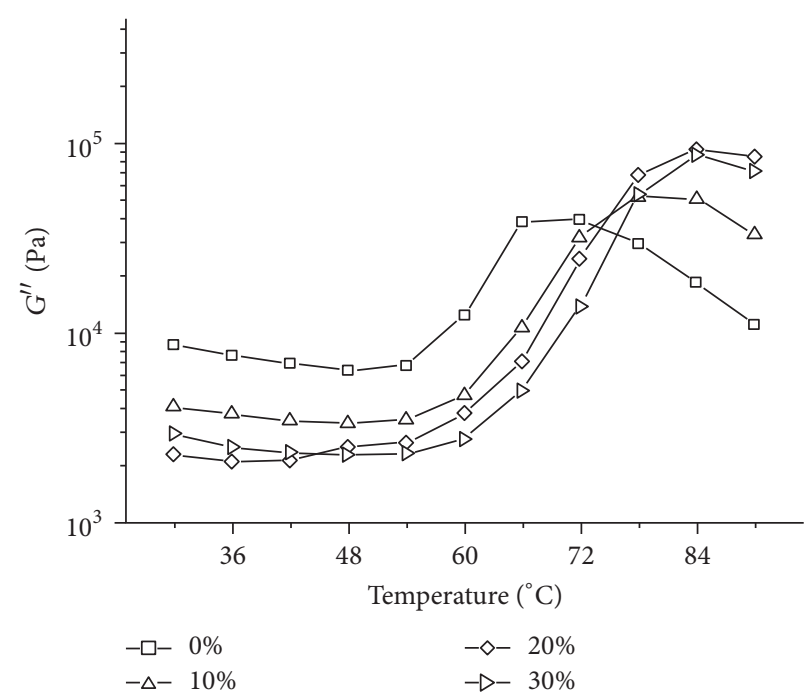

(b)

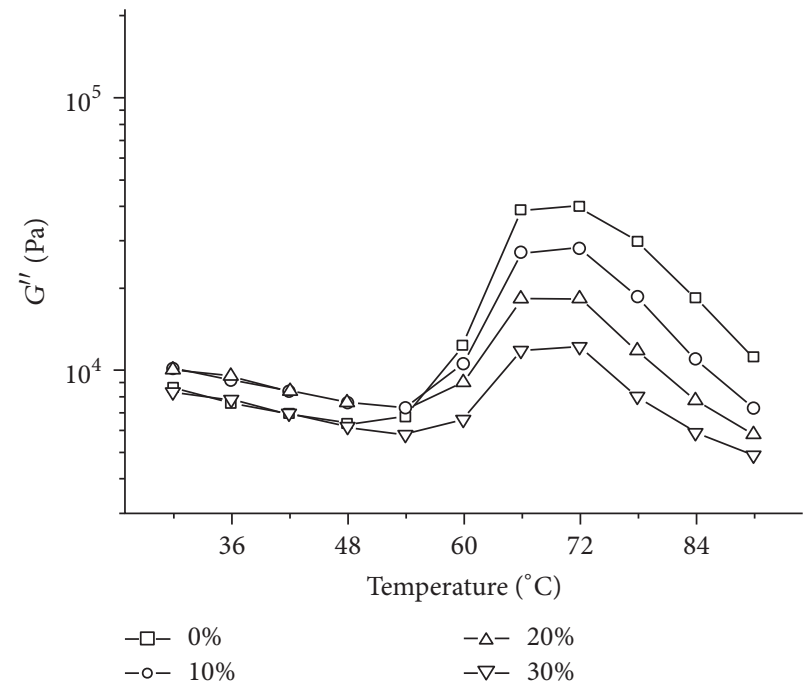

(d)

Figure 2: The effect of whey and soy protein addition on $G^{\prime}$ and $G^{\prime \prime}$ of wheat dough with temperature sweep: WP ((a), (b)); SP ((c), (d)).

component alone, meaning synergistic interactions between WP and starch [25]. Compared to WP, wheat-SP dough followed quite similar tendencies of $G^{\prime}$ and $G^{\prime \prime}$ as wheat dough control. The transition temperature was at $54^{\circ} \mathrm{C}$ and the temperature for the maximum value of $G^{\prime}$ and $G^{\prime \prime}$ was at $72^{\circ} \mathrm{C}$. However, $G^{\prime}$ and $G^{\prime \prime}$ decreased with the increasing concentration of SP because of decreased starch content of the dough and higher water absorption and weaker gelling effect of SP.

3.4. Scanning Electron Microscopy. The microstructure of wheat flour dough, as influenced by the substitution of $10 \%$ and $30 \%$ of WP and SP, is presented in Figure 3. Micrograph of wheat dough is shown in Figure 3(a). The figure presented that the dough had a relatively smooth surface and starch granules were embedded in the gluten matrix. To compare the effects of WP and SP enrichment, it was clearly seen from Figures 3(b) and 3(c) that starch granules were still partly embedded in the protein matrix due to the surface adhesion induced by WP. However, hollows or ditches were observed on the dough surface, indicating that the continuity of the gluten matrix had been disrupted by WP. With the addition of $10 \%$ SP (Figure 3(d)), it could be seen that starch granules were separated from the protein matrix meaning disruption in the well-defined protein-starch complex of wheat flour dough. However, the protein matrix composed of gluten and SP seemed more compact beyond fragmented areas, probably due to previously mentioned aggregation of SP and its higher water binding capacity. With the addition of $30 \%$ SP (Figure 3(e)), the aggregation of SP induced formation of soy protein network, which provided a protective effect on starch-protein complex, thus leading to higher stability and elasticity of the dough. 


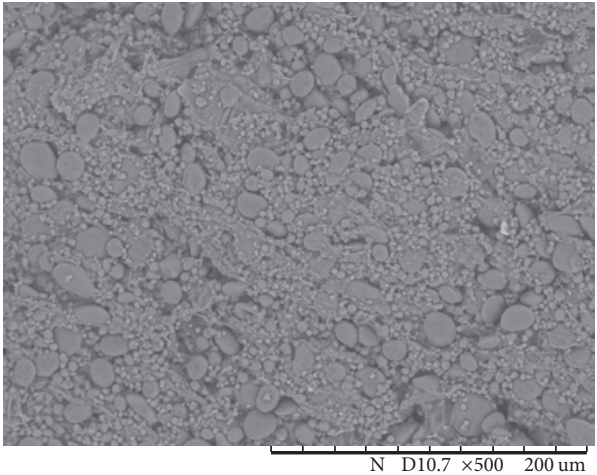

(a)

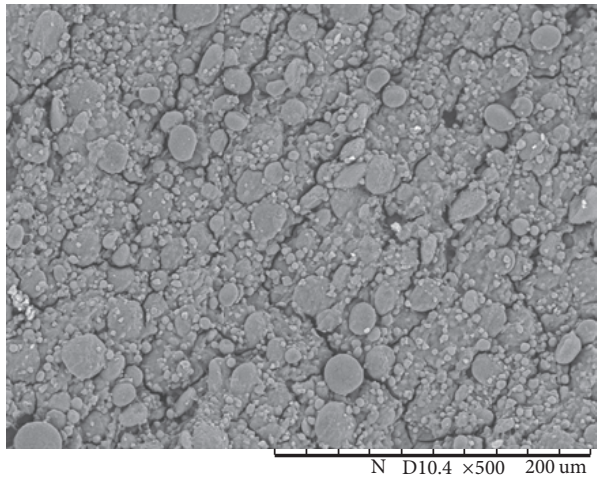

(c)

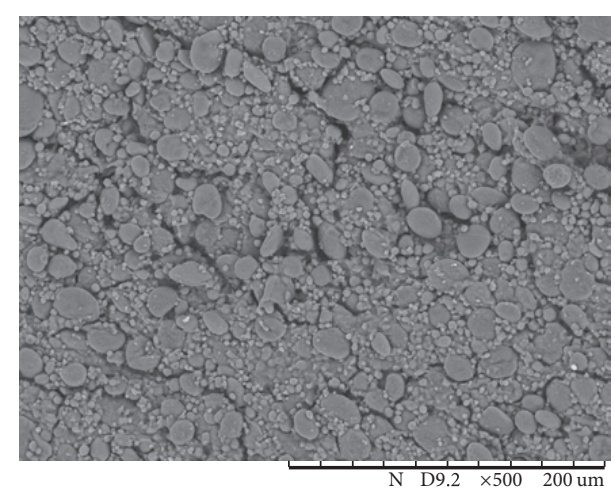

(b)

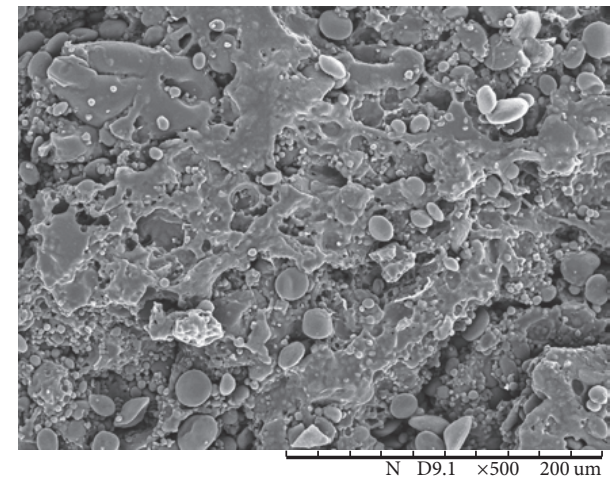

(d)

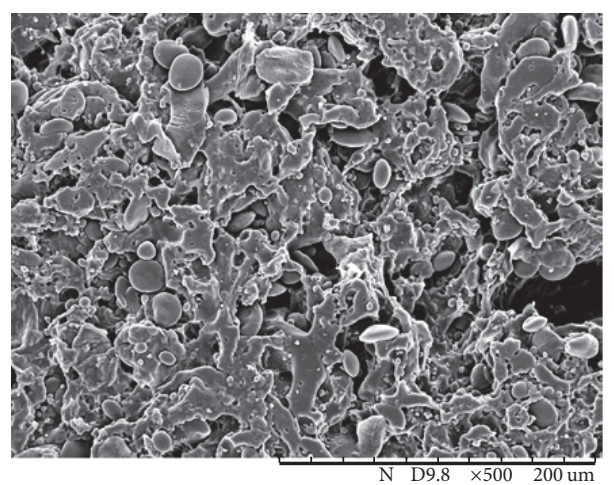

(e)

FIGURE 3: Scanning electron micrographs of dough with different percentage substitution of WP and SP: (a) Control; (b) Control + 10\% WP; (c) Control $+30 \% \mathrm{WP}$; (d) Control $+10 \%$ SP; (e) Control $+30 \%$ SP.

3.5. Cookie Quality Characteristics. Table 2 showed the effect of substitution of wheat flour with WP and SP on the quality parameters of cookies. Usually, higher spread ratio is considered as one of the desirable quality attributes [26]. From the results, the spread ratio of cookies continually decreased from 6.39 to 4.00 with the increase of WP content. Differently, the incorporation of SP decreased the cookie spread ratio from 6.39 to 5.66 and then increased to 6.86. The results above based on SP enrichment were not in agreement with previous studies [27-29], who reported a decrease in spread ratio of cookies with increase in proteins and concluded that the incorporation of foreign proteins interfered with gluten development and therefore had negative effects on baking products, especially when amount of foreign proteins was higher than 5\%. However, things were different when amount of SP was higher than gluten content. The aggregation of SP induced formation of soy protein network, which helped increase the elasticity and extensibility of the wheat dough, thus leading to increased spread ratio. The soy protein network might also confer a protective effect on partial gluten structure for obtaining an improvement in the quality of bakery products. The results were consistent with Mixolab measurements, which showed that both MMT and MST first decreased and then increased with the further increasing level 
TABLE 2: Effect of whey and soy protein addition on cookie quality parameters ${ }^{\mathrm{a}}$.

\begin{tabular}{|c|c|c|c|c|c|c|}
\hline & \multirow{2}{*}{$\begin{array}{l}\text { Spread ratio } \\
\qquad(D / T)\end{array}$} & \multirow{2}{*}{$\begin{array}{l}\text { Hardness } \\
\text { (g) }\end{array}$} & \multicolumn{4}{|c|}{ Color values } \\
\hline & & & $L^{*}$ & $a^{*}$ & $b^{*}$ & $\Delta E$ \\
\hline Control & $6.39 \pm 0.12^{\mathrm{fg}}$ & $4862.0 \pm 368.6^{\mathrm{b}}$ & $66.65 \pm 0.35^{f}$ & $10.21 \pm 0.25^{\mathrm{a}}$ & $33.78 \pm 0.69^{\mathrm{abc}}$ & 45.24 \\
\hline \multicolumn{7}{|c|}{ Whey protein } \\
\hline 5 & $6.27 \pm 0.23^{\mathrm{efg}}$ & $4110.2 \pm 360.3^{\mathrm{ab}}$ & $60.04 \pm 0.69^{\mathrm{de}}$ & $15.30 \pm 0.24^{\mathrm{e}}$ & $35.52 \pm 0.20^{\mathrm{cd}}$ & 52.30 \\
\hline 10 & $5.62 \pm 0.38^{\mathrm{cd}}$ & $4918.9 \pm 150.0^{\mathrm{b}}$ & $56.89 \pm 0.13^{\mathrm{cd}}$ & $17.87 \pm 0.11^{\mathrm{f}}$ & $36.27 \pm 0.18^{\mathrm{d}}$ & 55.81 \\
\hline 15 & $5.03 \pm 0.11^{b c}$ & $5834.9 \pm 496.1^{\mathrm{c}}$ & $53.16 \pm 1.20^{\mathrm{bc}}$ & $19.85 \pm 0.13^{\mathrm{g}}$ & $35.83 \pm 0.36^{\mathrm{d}}$ & 58.93 \\
\hline 20 & $4.54 \pm 0.09^{\mathrm{ab}}$ & $7129.4 \pm 312.0^{\mathrm{d}}$ & $51.03 \pm 1.38^{\mathrm{ab}}$ & $20.88 \pm 0.13^{\mathrm{gh}}$ & $35.39 \pm 0.64^{\mathrm{cd}}$ & 60.63 \\
\hline 25 & $4.30 \pm 0.25^{\mathrm{a}}$ & $7301.4 \pm 118.0^{\mathrm{d}}$ & $50.19 \pm 0.52^{\mathrm{ab}}$ & $21.46 \pm 0.12^{\mathrm{h}}$ & $35.30 \pm 0.68^{\mathrm{bcd}}$ & 61.42 \\
\hline 30 & $4.00 \pm 0.05^{\mathrm{a}}$ & $7504.3 \pm 125.2^{\mathrm{d}}$ & $47.34 \pm 0.89^{\mathrm{a}}$ & $21.68 \pm 0.15^{\mathrm{h}}$ & $33.27 \pm 0.22^{\mathrm{ab}}$ & 62.66 \\
\hline \multicolumn{7}{|c|}{ Soy protein } \\
\hline 5 & $5.92 \pm 0.22^{\mathrm{def}}$ & $4404.0 \pm 292.3^{\mathrm{ab}}$ & $66.13 \pm 1.39^{f}$ & $11.18 \pm 0.10^{\mathrm{ab}}$ & $33.12 \pm 0.78^{\mathrm{a}}$ & 45.36 \\
\hline 10 & $5.66 \pm 0.15^{\mathrm{de}}$ & $4472.7 \pm 260.0^{\mathrm{ab}}$ & $64.98 \pm 1.75^{\mathrm{f}}$ & $12.28 \pm 1.37^{\mathrm{bc}}$ & $33.25 \pm 0.86^{\mathrm{ab}}$ & 46.52 \\
\hline 15 & $6.05 \pm 0.08^{\mathrm{def}}$ & $4180.0 \pm 176.4^{\mathrm{ab}}$ & $63.95 \pm 0.59^{f}$ & $13.49 \pm 0.21^{\mathrm{cd}}$ & $33.71 \pm 0.54^{\mathrm{abc}}$ & 47.86 \\
\hline 20 & $6.26 \pm 0.11^{\mathrm{efg}}$ & $3900.8 \pm 363.0^{\mathrm{a}}$ & $62.95 \pm 1.00^{\mathrm{ef}}$ & $13.94 \pm 0.51^{\mathrm{de}}$ & $33.31 \pm 1.30^{\mathrm{ab}}$ & 48.43 \\
\hline 25 & $6.48 \pm 0.31^{\mathrm{fg}}$ & $3690.0 \pm 249.4^{\mathrm{a}}$ & $62.88 \pm 2.69^{\mathrm{ef}}$ & $14.24 \pm 0.73^{\mathrm{de}}$ & $34.63 \pm 0.63^{\mathrm{abcd}}$ & 49.43 \\
\hline 30 & $6.86 \pm 0.08^{\mathrm{g}}$ & $3872.6 \pm 103.0^{\mathrm{a}}$ & $64.73 \pm 0.56^{\mathrm{f}}$ & $14.18 \pm 0.37^{\mathrm{de}}$ & $34.25 \pm 0.37^{\mathrm{abcd}}$ & 47.89 \\
\hline
\end{tabular}

${ }^{\mathrm{a}}$ Data are presented as means \pm standard deviation. Data values with different letters in columns are significantly different, $p \leq 0.05$.

TABLE 3: Consumer acceptability (9-point hedonic scale) analysis.

\begin{tabular}{|c|c|c|c|c|c|}
\hline Sensory attributes & Overall acceptability & Hardness & Texture/mouth feel & Color/appearance & Flavor \\
\hline Control & 6.9 & 6.3 & 7.0 & 7.2 & 7.1 \\
\hline \multicolumn{6}{|l|}{ Whey protein } \\
\hline 10 & 6.2 & 6.0 & 5.7 & 5.5 & 7.1 \\
\hline 20 & 4.6 & 4.8 & 4.0 & 3.9 & 5.4 \\
\hline 30 & 3.7 & 4.2 & 3.2 & 2.7 & 4.3 \\
\hline \multicolumn{6}{|l|}{ Soy protein } \\
\hline 10 & 6.6 & 6.4 & 6.3 & 7.4 & 6.9 \\
\hline 20 & 6.8 & 6.9 & 6.6 & 6.9 & 6.5 \\
\hline 30 & 7.0 & 7.2 & 7.1 & 7.1 & 6.5 \\
\hline
\end{tabular}

of SP. The results indicated that the selection of the protein source and amount with appropriate functionalities seemed to play an important role in certain application.

The texture was also markedly affected with increasing level of WP and SP. The hardness indicated by breaking force in Table 2 increased with the increase in the level of WP but decreased with the increase in the level of SP. Compared to SP, $\mathrm{WP}$ is a much better gelling protein [30]. The heat-induced gelation of WP led to higher stiffness of cookie dough. The colors of cookies, which was represented by $L^{*}, a^{*}, b^{*}$, and $\Delta E$ values, were summarized in Table 2. $L^{*}$ values represent the lightness of the cookies by level 0-100. Redness of cookies is donated by $a^{*}$ values. The $b^{*}$ values suggest the yellowness of cookies. With increase in WP from 0 to $30 \%$, there were significant decrease in $L^{*}$ and increase in $a^{*}$, meaning lower lightness and higher redness of cookies. The rapid increase of $\Delta E$ with addition of WP indicated the darker color of cookies, which was mainly attributed to Maillard reactions between sugar and free amino acids provided by WP. Compared to wheat flour control, slight changes in color were observed for SP fortified cookies.
3.6. Consumer Acceptability Test. Table 3 shows the consumer acceptability ratings for various sensory attributes of cookies. With the addition of WP, the scores of all sensory attributes and overall acceptability of the cookies decreased, especially scores of color and texture. The maximum amount of WP in the cookie that could be accepted by consumers was $10 \%$. With the addition of SP, the scores of hardness increased and the scores of texture first decreased and then increased. The overall acceptability also first decreased from 6.9 to 6.6 and then increased to 7.0, which meant the cookies fortified with soy proteins (0-30\%) are all acceptable and even preferred by consumers, especially when higher amount of soy protein (like 30\% replacement ratio) was applied.

\section{Conclusions}

The effect of soy and whey proteins on the thermomechanical, dynamic rheological, and microstructural properties of wheat dough and the cookie-making quality was compared in this work. The dilution of gluten by WP addition and thereby disruption of gluten structure led to lower quality 
of wheat dough and final cookie products. Differently, the aggregation of SP induced formation of soy protein network, which helped increase the elasticity and extensibility of the wheat dough and confer a protective effect on partial gluten structure, thus leading to increased spread ratio and overall acceptability of the cookies, especially when higher amount of SP was incorporated. The results indicated that selection of the protein source and amount with appropriate functionalities played an important role in certain applications of protein fortified bakery products. Further studies will be needed to explore the changes of protein structure and network for SP fortified cookies.

\section{Conflicts of Interest}

The authors declare that they have no conflicts of interest.

\section{Acknowledgments}

The authors would like to acknowledge Key University Science Research Project of Jiangsu Province for funding this project (Grant no. 12KJA550002). The project was also funded by the Priority Academic Program Development of Jiangsu Higher Education Institutions (PAPDF). The authors acknowledge the support from 2013 Jiangsu University Outstanding Science and Technology Innovation Team.

\section{References}

[1] C. R. Storck, E. da Rosa Zavareze, M. A. Gularte, M. C. Elias, C. M. Rosell, and A. R. Guerra Dias, "Protein enrichment and its effects on gluten-free bread characteristics," LWT - Food Science and Technology, vol. 53, no. 1, pp. 346-354, 2013.

[2] C. Li, H. Enomoto, S. Ohki, H. Ohtomo, and T. Aoki, "Improvement of functional properties of whey protein isolate through glycation and phosphorylation by dry heating," Journal of Dairy Science, vol. 88, pp. 4137-4145, 2005.

[3] A. S. Ammar, S. A. Salem, and F. H. Badr, "Rheological properties of wheat flour dough as affected by addition of whey and soy proteins," Pakistan Journal of Nutrition, vol. 10, no. 4, pp. 302-306, 2011.

[4] S. Dhingra and S. Jood, "Organoleptic and nutritional evaluation of wheat breads supplemented with soybean and barley flour," Food Chemistry, vol. 77, no. 4, pp. 479-488, 2002.

[5] D. Indrani, P. Prabhasankar, J. Rajiv, and G. V. Rao, "Influence of whey protein concentrate on the rheological characteristics of dough, microstructure and quality of unleavened flat bread (parotta)," Food Research International, vol. 40, no. 10, pp. 12541260, 2007.

[6] S. Kenny, K. Wehrle, M. Auty, and E. K. Arendt, "Influence of sodium caseinate and whey protein on baking properties and rheology of frozen dough," Cereal Chemistry, vol. 78, no. 4, pp. 458-463, 2001.

[7] P. D. Ribotta, S. A. Arnulphi, A. E. Leon, and M. C. Anon, "Effect of soybean addition on the rheological properties and breadmaking quality of wheat flour," Journal of the Science of Food and Agriculture, vol. 85, pp. 1889-1896, 2005.

[8] M. Sudha, G. Rajeswari, and G. V. Rao, "Influence of defatted soy flour and whey protein concentrate on dough rheological characteristics and quality of instant vermicelli," Journal of Texture Studies, vol. 42, pp. 72-80, 2011.

[9] R. Crockett, P. Ie, and Y. Vodovotz, "Effects of soy protein isolate and egg white solids on the physicochemical properties of gluten-free bread," Food Chemistry, vol. 129, no. 1, pp. 84-91, 2011.

[10] C. Marco and C. M. Rosell, "Runctional and rheological properties of protein enriched gluten free composite flours," Journal of Food Engineering, vol. 88, pp. 94-103, 2008.

[11] D. Sağlam, P. Venema, R. de Vries, J. Shi, and E. van der Linden, "Concentrated whey protein particle dispersions: heat stability and rheological properties," Food Hydrocol, vol. 30, pp. 100-109, 2013.

[12] T. D. Hadnađev, A. Torbica, and M. Hadnađev, "Rheological properties of wheat flour substitutes/alternative crops assessed by Mixolab," Procedia Food Science, vol. 1, pp. 328-334, 2011.

[13] W. Chen and R. Hoseney, "Development of an objective method for dough stickiness," LWT-Food Sci. Technol., vol. 28, pp. 467473, 1995.

[14] AACC, "Approved methods of the American Association of Cereal Chemists," in The Amer. Assoc. Cereal Chem, The Amer. Assoc. Cereal Chem. Inc., St. Paul, Minn, USA, 2000.

[15] C. M. Rosell, C. Collar, and M. Haros, "Assessment of hydrocolloid effects on the thermo-mechanical properties of wheat using the Mixolab," Food Hydrocolloids, vol. 21, no. 3, pp. 452462, 2007.

[16] J. G. Zadow, "Measurement of the effect of whey protein concentrates on fermenting doughs by the Instron Tester," Australian Journal of Dairy Technology, vol. 36, pp. 56-59, 1981.

[17] C. C. Kim and C. E. Walker, "Changes in starch pasting properties due to sugars and emulsifiers as determined by viscosity measurement," Journal of Food Science, vol. 57, pp. 1009-1013, 1992.

[18] C. Marco and C. M. Rosell, "Effect of different protein isolates and transglutaminase on rice flour properties," Journal of Food Engineering, vol. 84, pp. 132-139, 2008.

[19] J. Shim and S. J. Mulvaney, "Effect of heating temperature, $\mathrm{pH}$, concentration and starch/whey protein ratio on the viscoelastic properties of corn starch/whey protein mixed gels," Journal of the Science of Food and Agriculture, vol. 81, pp. 706-717, 2001.

[20] S. F. Dogan, S. Sahin, and G. Sumnu, "Effects of soy and rice flour addition on batter rheology and quality of deep-fat chicken nuggets," J. Food Eng, vol. 71, pp. 127-132, 2005.

[21] R. C. Hoseney and J. Smewing, "Instrumental measurement of stickiness of doughs and other foods," Journal of Texture Studies, vol. 30, no. 2, pp. 123-136, 1999.

[22] M. Heitmann, E. Zannini, and E. K. Arendt, "Impact of different beer yeasts on wheat dough and bread quality parameters," Journal of Cereal Science, vol. 63, pp. 49-56, 2015.

[23] E. J. van Velzen, J. P. van Duynhoven, P. Pudney, P. L. Weegels, and J. H. van der Maas, "Factors associated with dough stickiness as sensed by attenuated total reflectance infrared spectroscopy," Cereal Chem, vol. 80, pp. 378-382, 2003.

[24] K. Addo, Y. Xiong, and S. Blanchard, "Thermal and dynamic rheological properties of wheat flour fractions," Food Research International, vol. 34, pp. 329-335, 2001.

[25] J. M. Aguilera and E. Rojas, "Rheological, thermal and microstructural properties of whey protein-cassava starch gels," Journal of Food Science, vol. 61, no. 5, pp. 962-966, 1996.

[26] H. Yamamoto, S. T. Worthington, G. Hou, and P. Ng, "Rheological properties and baking qualities of selected soft wheats in the United States," Cereal Chem, vol. 73, pp. 215-221, 1996. 
[27] S. Barak, D. Mudgil, and B. S. Khatkar, "Effect of composition of gluten proteins and dough rheological properties on the cookimaking quality," British Food Journal, vol. 115, pp. 564-574, 2013.

[28] K. H. McWatters, "Cookie baking properties of defatted peanut, soybean and field pea flours," Cereal Chem, vol. 55, pp. 953-863, 1978.

[29] B. Singh, M. Bajaj, S. Sharma, and J. S. Sidhu, "Studies on the development of high-protein biscuits from composite flours," Plant Foods for Human Nutrition, vol. 43, pp. 181-189, 1993.

[30] S. Comfort and N. K. Howell, "Gelation properties of soya and whey protein isolate mixtures," Food Hydrocolloids, vol. 16, no. 6, pp. 661-672, 2002. 

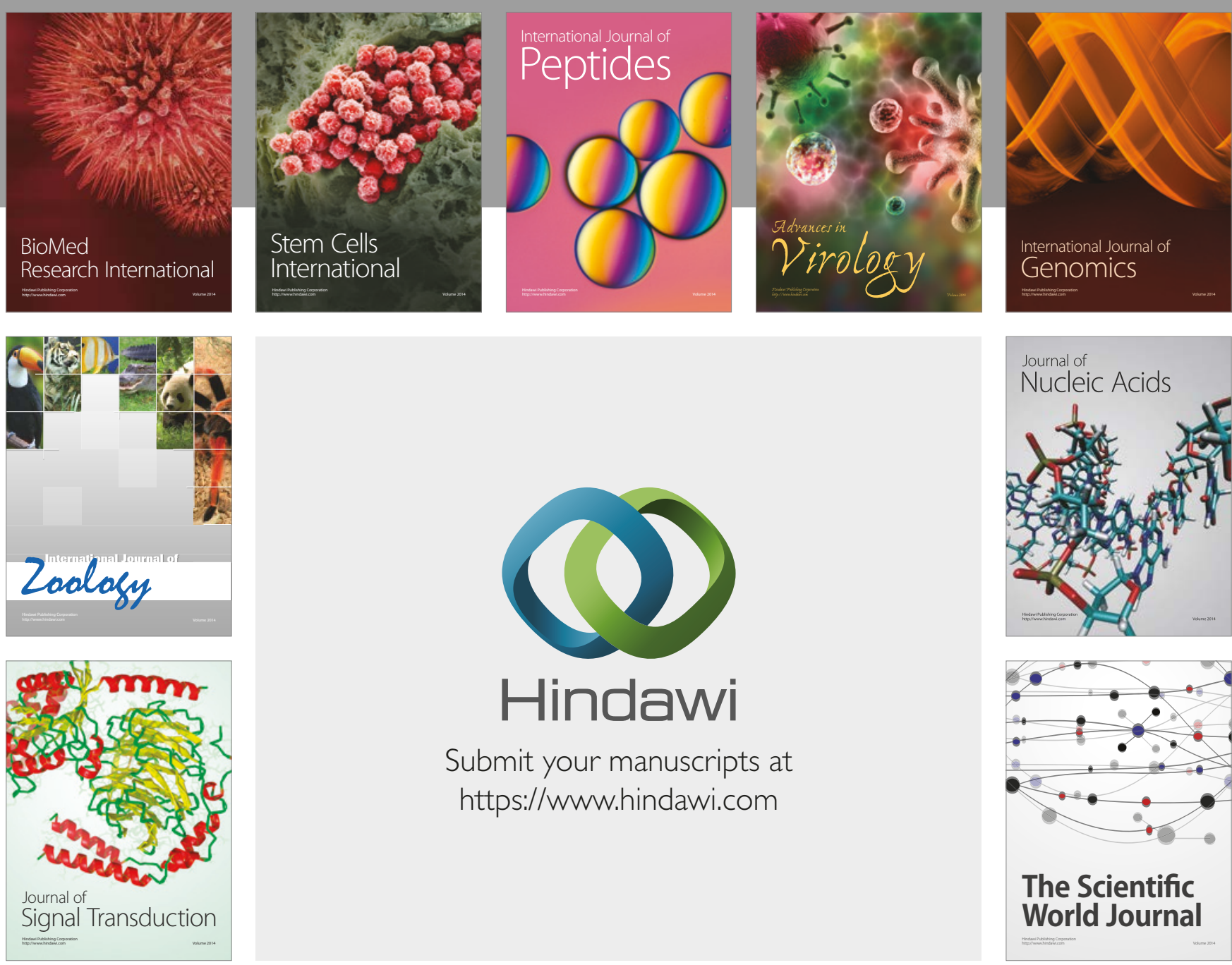

Submit your manuscripts at

https://www.hindawi.com
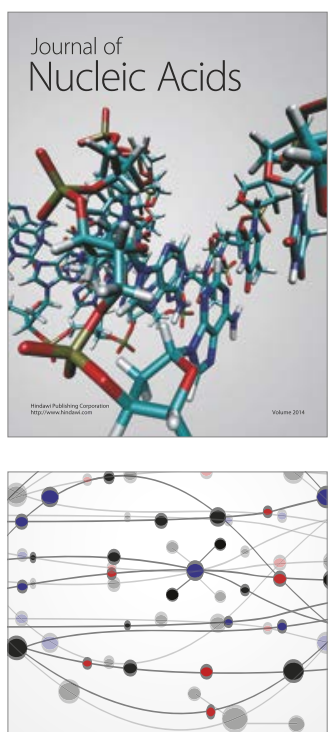

The Scientific World Journal

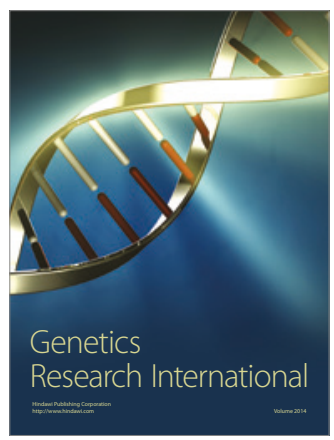

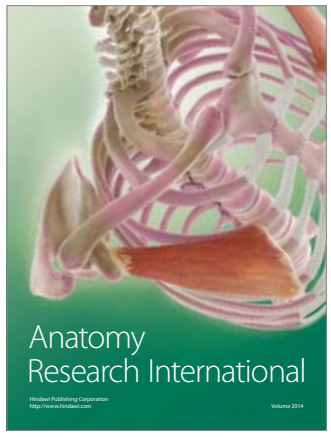

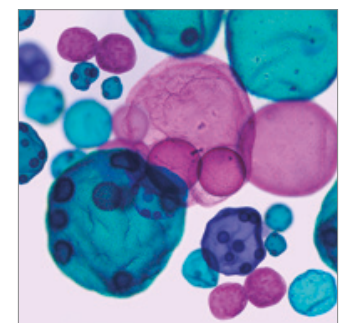

International Journal of Microbiology
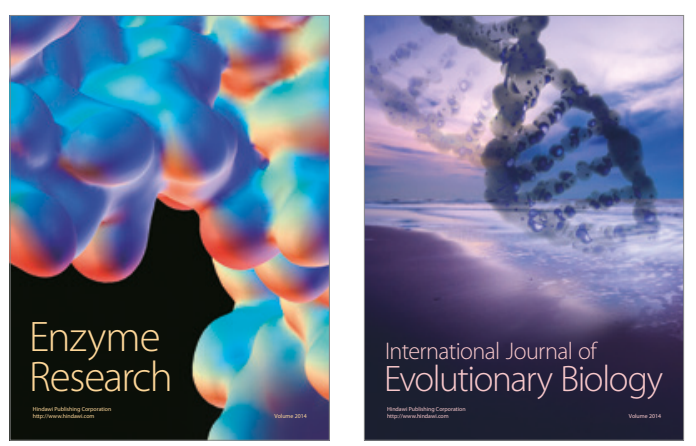
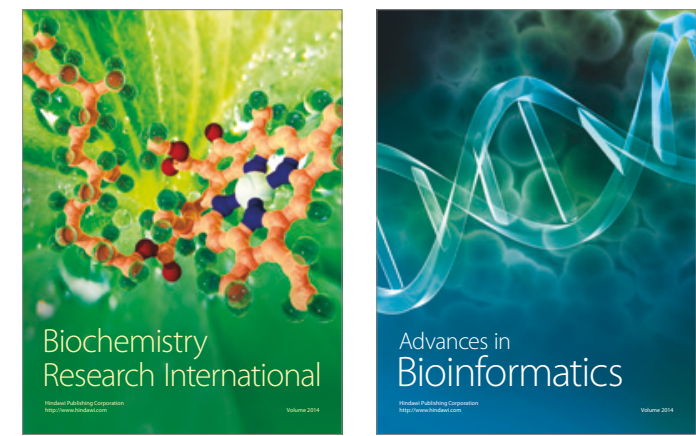

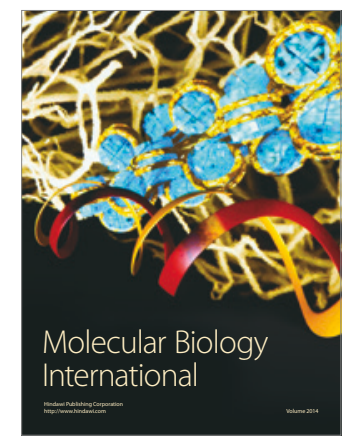

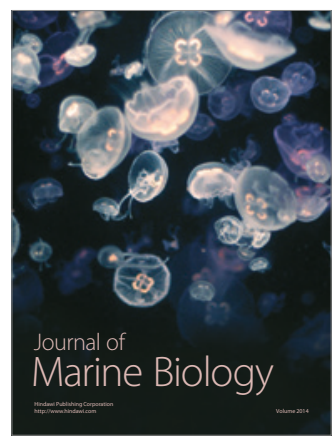

